\title{
What Is New in Muslim Faith? Global Conflicts versus Moral Interests
}

\author{
Mahgoub El-Tigani Mahmoud \\ Department of Sociology, Social Work \& Urban Professions, Tennessee State University, Nashville, USA \\ Email: mmahmoud@Tnstate.edu
}

Received October $7^{\text {th }}$, 2013; revised November $7^{\text {th }}$, 2013; accepted November $14^{\text {th }}, 2013$

\begin{abstract}
Copyright @ 2013 Mahgoub El-Tigani Mahmoud. This is an open access article distributed under the Creative Commons Attribution License, which permits unrestricted use, distribution, and reproduction in any medium, provided the original work is properly cited.
\end{abstract}

\begin{abstract}
This paper ascertains genuine principles of Islam while exploring an emerging contradiction between authentic tenets of faith in the Muslims' heritage of human rights and justice, and a variety of modern targets upheld by OIC Charter and other political and legal instruments to guide a far-sighted authority agenda in pursuit of global equilibrium over key Muslim concerns. The paper ends with operational strategies on sooth conflicting situations of this complex dilemma.
\end{abstract}

Keywords: Islam; Faith; Holy Qur’an; Muhammad; Muslims; OIC; Reform; International Law; Globalization; Underdevelopment

\section{Introduction}

This paper assumes that here are genuine differences, as well as possible agreements between authentic tenets of Islam and the international principles on human rights and justice. While Muslim governments' developmental efforts emphasize states' security and military build-up, intellectual works address the dire need of Muslims to attend key industrial and agricultural advancement, fair production relations, and radical improvements for the life of the vast majority of Muslim populations all over the world. Comparisons between Muslim entities and the non-Muslim western nations reveal unattended challenges of progression by Muslim states despite immense pressures for reform by judicial, educational, and other occupational professionals and activists.

The challenges facing Muslim nations today had been equally facing non-Muslim individuals and groups. What was not quite clear for most westerners and other world entities, however, was that the same challenges of living in peace and prosperity with the full enjoyment of human rights and fundamental freedoms for non-Muslim populations resembled the same and one requirement for Muslims to exercise full enjoyment of Islam. As we see it, this philosophical issue is precisely the reason why serious rethinking of East-West, Muslim-nonMuslim hostilities should be strongly advanced to end the crisis.

\section{Human Rights, Peace and Justice Are the Tenets of Islam}

\section{Islam, a Free Will to Faith}

A book of faith in essence, the stories, parables, rules, guidance and commanding teachings of the Qur'an, the Holy Book of Islam, were revealed unto Muhammad, the Prophet of Islam, to create a deep level of belief in Allah, the Almighty God.
Allah ordered Muhammad to call upon humans to believe in Islam, but Allah never required Muhammad, himself the greatest Muslim, to "control" or to "master" any human to be an adherent of Islam or the Holy Book of Islam. The Book explained in several verses that "God guides as He wishes." God said to the Prophet in the Holy Qur'an: "Zak-kir!” "Do though give admonition, for thou art one to admonish. Thou art not one to manage (men’s) affairs” (Gashiya, verses 91 and 92).

This free choice of a believer's optional faith in Islam led to another clear position regarding the progressive mission of Islam. Precisely, no one person, group, or government on earth could be authorized, in principle, to force humans to convert to Islam or to any other religion or faith for "Let there be no compulsion in religion” (Baqara: 256). Once a human adopted Islam with full consent, the decision would rightly become a matter of personal commitment. It followed that the degree of a human's adherence to the teachings of Islam would be a matter of individual consciousness and struggle more than adherence to any organizational body or external authority. This flexibility of faith never meant that community-based activity for the service of people was not a Muslim's social obligation (Mahmoud, 2013: p. 329).

A religion for peace, justice, and human rights, Islam is a motive for ethical and humanitarian commitments. Wrongs or atrocities committed in the name of Islam should be attributed to the wrong-doers, individuals, groups, organizations, or governments in accordance with their own motivating ideas and/or deeds. Applying this clear understanding of Islam, the extremist interpretations and the organizational activities by al-Qaida in Afghanistan, al-Shabab in Somalia, Muslim Brotherhood Alwiya, and many other non-integrationist Jihadist militant groups, as well as aggressive acts by warring governments, constituted mutual gross violations of these peaceful fixations, namely the free choice of faith, prohibition of transgression, and the cherishment of religious tolerance with respect to both 
Muslim and non-Muslim peoples.

Integrationist entities, for example the Arab League and the Organization of Islamic Conference (OIC), preferred to stay at a distance from the tragedies of violence in the Muslim world, instead of taking decisive stands to stop excesses of these antagonistic activists against the civilized, sacred, and genuine realm of Islam. In the meantime, most global powers failed in the process of negotiating consistently peaceful resolutions to this international crisis via mutual understanding, brave mediation, and tolerant arbitration. Eventually, global powers have been strongly invited by millions of Muslims to develop authentic knowledge about the faith and jurisprudence of Islam for the cause of peace, more than escalating the warring measures thus far implemented against Muslim militants.

\section{Islam, the Holy Qur'an and Muhammad's Life}

A misconception that Islam was a religion affording a special patronage of some Muslims over the other Muslims or nonMuslims was firmly rejected by a vast majority of the earlier Muslims, as well as succeeding generations, as dangerous, nonreligious, and flagrant intimidation of people by a misguided philosophy or authority-seekers.

Throughout the history of Muslim Sufism, for example, almost all Sufi sects were acceptable to a massive majority of Muslims because they had been founded on the respect of fitra [the good nature of humanity]. Arguing against misconceptions of Muslim faith, Nabil Loga Babawi (2002: p. 46), a devout Christian thinker, ascertained the fact that "Islam is a religion of peace and friendship between all peoples. Islam is not for violence and civilization conflicts. It is a religion that recognizes the obligation of all peoples on earth to cooperate with one another, not to make wars with one another. The Qur'an says ' $\mathrm{O}$ mankind! We created you from a single (pair) of a male and female, and made you unto nations and tribes, that ye may know each other (Hujurat: 13)'.”

The Prophet of Islam paid full respect to the right of humans to choose the faith they wanted, while still calling on them to adopt Islam. When the Apostle triumphed over Quraish, he generously asked them to "Go! You are free!" The patience, justice, and wisdom of the Prophet articulated in his daily life: Muhammad presented a living example of the ideals of humane behavior, even in situations of inflicting the hudud physical punishments. He taught the Muslims to avoid implementation of the hudud more than any jurist or thinker possibly did. To enjoy a healthy productive life in accordance with the Qur'an and the Sunna, there was a high level of explicit spiritual and moral commitments, in addition to teachings implied by the Prophet's Hadith on al-Jihad al-Akber, that of one's evil tendencies, the greatest struggle of individual Muslims. A Muslim was entitled a right to adjudicate; but God would reward him if he pardoned the offender instead of having him punished by law.

\section{Muslim Beliefs and Governance}

The governments of Muslim societies should confine public energies and legal authorities to serve the citizens' constitutional rights without discrimination by race, religion, gender, political stand, or economic status criteria. Because religious activities were naturally biased to a religion's supporters, they were largely considered community affairs and personal rights, not a State business. Islam had been revealed as a fitra path of life [natural right of people to think and act on their own without interference], Muslims were best advised to dispose of their energies to please God by the service of the needy and the poor, in addition to the provision of education, health, and other useful programs, instead of imposing individualistic faith preferences on people-as previously explained in this paper.

Isma'il al-Faruqi (2009) explained in the area of legislation, "The Islamic bill of human rights is a system of axiological principles or clauses... elaborated in the shari'ah... except in a few cases, the letter of the prescriptive elaborations of human rights in Islam is not sacrosanct and hence absolutely inalterable. Eternity and absoluteness belong in the main, to the axiological postulates. With the exception of these postulates and directions, all deontological elaborations... of the shari'ah are ever-open to interpretations by humans." Sayed Radwan's (2003: p. 15) eloquent statement further concluded: "the discourse of development in the two civilization spaces, Europe and the Muslim World, was different: The Church was in control of the religious affair (the image of the World) and the political affair (the Roman Sacred Empire). The Islamic religious institution (which was largely different from its Catholic counterpart) did not control the religious or the political affairs in the old or in the new ages."

The imposition of Islam by the so-called Islamization doctrine on State or community affairs, especially by government authorities or the political parties that hide behind them-resembled authoritative political entities and/or state bodies in Muslim societies today. The activities of these groups antagonized the peaceful principles of Islam as they harassed the populace by religious intolerance in gross violation of Islam, unlike the conduct of the Prophet of Islam whose godly mission centered on the call on humanity to adopt Islam peacefully. The Prophet's Sahaba [disciples] struggled as both public figures and individual Muslims to spread the Prophet's call in the known world under difficult conditions of hostilities and selfdefense, including positive responsiveness to support powerless believers or needy populations. Here, the question is: have the new formations of Muslim groups adopted the noble teachings of the Prophet and the same struggles of the honorable Sahaba to operate the faith of Islam?

\section{The OIC Commitments}

The Charter of the Organization of the Islamic Conference (OIC) as a new Muslim world group, stated that the OIC was determined "to be guided by the noble Islamic values of unity and fraternity, and affirming the essentiality of promoting and consolidating the unity and solidarity among the Member States in securing their common interests at the international arena" (International Center for Not-to-Profit Law (ICNL 2008). Amending the Rabat (1969) and the Jeddah (1972) OIC's founding charter, the new 2008 charter was adopted during the 11th OIC Summit in Dakar "in the absence of several prominent leaders... to promote democracy, good governance, and human rights" (Suparno, 2008); but the ratification of the charter and its operationalization has not decisively changed the routine performance of the member states.

That most Muslim nations had been led by governments placing power interests above "the noble Islamic values of unity and fraternity, and affirming the essentiality of promoting and consolidating the unity and solidarity among the Member States in securing their common interests at the international 
arena” was common knowledge: Hamza Hendawi (Cairo, 2013) reported a clear account "on the Organization of Islamic Cooperation Summit: Muslim Leaders Divided on Syria, Mali Crises Solution" due to unresolvable intra-conflicts between Iran-Gulf States and Syria-Arab States almost inhibiting normal relations among Sunni-dominated versus Shiite-controlled Muslim states. Moreover, mounting tensions between Turkey versus Iraq and Syria, and/or hostilities between Muslim contending groups in Somalia, Yemen, Libya, Algeria, Tunisia, and Mali jeopardized the development of these nations for decades.

The OIC commitment "to adhere our commitment to the principles of the United Nations Charter, the present Charter and International Law; to preserve and promote the lofty Islamic values of peace, compassion, tolerance, equality, justice and human dignity" had been virtually a subject of strategic interests rather than Islamic essence for Iran and other Member States which rejected fully the International Criminal Court decision to bring the Sudanese president Omer al-Bashir before the ICC, accused of specific war crimes in Darfur. These war crimes resulted in the extra-judicial killings of 300,000 estimated victims, the displacement of 2.7 million uprooted citizens, and the destruction of property, animal wealth, and land acquisitions.

This occurred in March, 2009, when the Iranian-led Islamists, most particularly the Palestinian Hamas, the International Union of Muslim "Ulama, and the OIC denounced in strong terms the ICC” (4 March, 2009) decision to arrest Omer al-Bashir for crimes against humanity in Darfur. Equally importantly, nonMuslim nations as important as China did not put pressure on the warring groups to comply with international law by abandoning arms shipments to the ruling regime in the first place, as the Wise Leader of South Africa Nelson Mandela forcefully decided. In open defiance to their commitments to international norms, many Muslim States sent parliamentarian delegates to support the president at Khartoum versus the ICC decision.

These legislators considered the ICC Prosecutor General "a political employee of Western powers," and then accused the ICC of "imperialist conspiracies" and "gross violations of international law" because the ICC dared to accuse the indicted president and must, therefore, rescind the decision, somehow, or be prepared for caricaturing, political accusations, and other impulsive reactions. All of the promised threats occurred: following the ICC decision, the speaker of the Iranian Parliament "Ali Largani, the chief of Hamas political bureau Khalid Mish'al, and OIC secretary general, besides a number of several Islamist experts on international law joined the beleaguered president and his aides, led by vice president” Ali Osman, to discredit the ICC decision as "totally irrelevant; and unworthy of attention” (El-Tigani, 2009).

Other than humanitarian aid primarily provided by the UN, USA, Canada and European relief agencies with Saudi Aid (Barasi, 2005), Qatar (Baatout, 2013), and a few other Muslim donors to the distressed region of Darfur, the OIC obligation to "ensuring sustainable development, progress and prosperity for the peoples of Member States; and to enhance and strengthen the bond of unity and solidarity among the Muslim peoples and Member States" has been hardly felt by the beleaguered victims of the war the Muslim Brotherhood-dominated regime (1985 to the present) waged and further escalated against Darfur and her people by unprecedented military and financial support from the Government of Iran and lucrative oil returns. In 2010, the OIC pledged \$850 million to aid Darfur (Baladuf, 2010); and yet, this amount remained to be seen. Most important, the people of Darfur who disdained the authorities' corruption preferred security and stability over foreign aid (Baatout, 2013).

The OIC claim to promote human rights and fundamental freedoms, good governance, rule of law, democracy and accountability in Member States in accordance with their constitutional and legal systems was perhaps the most criticized of all OIC's obligations by charter. Here, a whole persistent series of gross human rights' violations had been increasingly reported against civil society organizations, political opponents, women activists, and other vulnerable human rights' advocates without adequate response from OIC states (AOHR 2001).

Furthermore, it sufficed to mention the repressive experiences of Taliban in Afghanistan, the political impositions of dictatorial rule under Islamic banners many times in Pakistan, Iraq, and Gaza, and the most recent conflict in Egypt versus an "elected" Muslim Brotherhood demagogic government which repressive planning and pronounced autocracy versus the popular will of most Egyptians were only possibly curtailed to salvage the deeply-rooted civil-minded society in the country by a joint offensive involving the armed forces and a broad alliance of people in the 30ieth of June 2013.

Muslims were equally victimized by violent non-Muslim assaults. For example, Thomas Fuller (2013) reported that in Myanmar, "Hatred and mistrust are especially deep between Muslims and Buddhists in Rakhine State, which borders Bangladesh. Last year, more than 150 people were killed and well over 100,000 were forced from their homes in the state.” Khin Maung Win (2013) reported similar atrocities: "Sectarian clashes that began in June 2012 have since morphed into an anti-Muslim campaign that has spread to towns and villages nationwide. So far, hundreds of people have been killed and more than 140,000 have fled their homes, the vast majority of them Muslims.”

Notwithstanding these critiques, the OIC pledge "to endeavor to work for revitalizing Islam's pioneering role in the world while ensuring sustainable development, progress and prosperity for the peoples of Member States; and to contribute to international peace and security, understanding and dialogue among civilizations, cultures and religions; and to foster noble Islamic values concerning moderation, tolerance, respect for diversity, preservation of Islamic symbols and common heritage and to defend the universality of Islamic religion" were attainable objectives of which the OIC achieved relative success in Inter-Faith conferences, besides similar activities in the regional and international arenas that supported the East-West intellectual debates, including intriguing Muslim-Christian dialogues.

The OIC efforts "to promote cooperation among Member States to achieve sustained socioeconomic development for effective integration in the global economy, in conformity with the principles of partnership and equality" made relatively important contributions to the national economies of a few Muslim nations, still far behind the overwhelming development projects, loans and other finances by the West vis-à-vis the Arab and Islamic inputs that had been founded on similar systems of borrowing and compounding interest values.

\section{The Underdevelopment of Muslim Populations}

Abdikadir Ibrahim (2011) noted that "The Muslim world faces the challenges of war, poor healthcare, poverty and violations of human rights, illiteracy, [lacking] of progress, dictator- 
ship, [lacking] of political transparency, ethnic conflict, and regional divisions. Illiteracy is a problem in majority of Muslim countries. We know all these problems are interconnected... Islamophobes blame Islam as the cause of the backwardness of Muslim nations. But the reality is contrary to that. Islam is a religion of progress, innovation, and development. It is a religion of every generation, time, and location. It is a religion of civilization; it is a way of life."

Emphasizing the role western colonialism played in Muslim colonized societies, Ibrahim affirmed: "Corruption, totalitarian dictatorship and deprivation of basic human rights such as education, freedom of speech, free enterprise, political participation, to name a few became the normal practice of governments... This leads to low human development index, which is measured by three indicators-life expectancy at birth, (long and healthy life), literacy, and income. The majority of Muslim nations fall in the low middle or bottom of the list in all these indicators according to the UN report on Human Development Index.

"In the entire Muslim World (57 Muslim Countries), there are around 500 universities. On the other hand, there are 5758 universities in the USA alone, and 8407 universities in India. In a research done by the UNDP in 2004, not one university in the entire Muslim world was featured in the top 500 ranking universities of the world. Literacy in the western world, predominantly Christian, is $90 \%$, whereas the literacy of the Muslim world is $40 \%$. Furthermore, $98 \%$ of these predominantly Western countries completed at least primary education, whereas only $50 \%$ of Muslim countries completed primary education. Similarly, $40 \%$ of western countries attended university, whereas only $2 \%$ of Muslim countries attended university."

Farooqi (2012) criticized correctly the failures of Muslim states to boost development: "Muslim nations, in spite of the poverty of their people are involved in this mad race for military might. They have large trained armies, which are estimated to be 100 million. This is one third of the total world armed forces... except the recent Iraq and Afghanistan crises but there have been several bloody wars amongst Muslim nations themselves in which millions have lost their lives. Muslim nations spend $10 \%-30 \%$ of their GDP towards purchasing sophisticated and deadly arms and ammunitions from the West... several factors for the backwardness of the Muslim society... illiteracy in general and women illiteracy in particular... $16 \%$ of population is involved in industrial production and high population growth.

"Human Development Index prepared by UNDP gives a very dismal picture of the status of literacy, health and economy of Muslim nations. In the first 25 best countries listed under HDI (2002), no Muslim country figured in the list. Barring few small oil producing Muslim nations, majority of the Islamic world lies in the middle and low categories of human development, a clear indication that the Islamic nations needs to increase their focus on human development.”

The OIC position "to safeguard and promote the rights of women and their participation in all spheres of life, in accordance with the laws and legislation of Member States” in actual fact had been at loggerhead with women's activism, especially the struggles of Muslim women to ensure the guarantees Islam provided for women to co-exist as equal partners of men in family, business, politics, and all other affairs of the social life. The tendencies of many Muslim rulers, in general, and Muslim jurists, in particular, to interpret the Shari'a Law of Islam to restrict women's equalitarian status and role in society had been strongly criticized by women activists (for example, Fatima Ahmed Ibrahim in Sudan, Nawal al Saadawi in Egypt, and Shireen Ebadi in Iran).

The OIC Charter dictated that OIC should "create conducive conditions for sound upbringing of Muslim children and youth, and to inculcate in them Islamic values through education for strengthening their cultural, social, moral and ethical ideals; to assist Muslim minorities and communities outside the Member States to preserve their dignity, cultural and religious identity.” The situation of education, however, was a source of dissatisfaction to both of the Muslim and the non-Muslim secularists in the Islamic world whenever Muslim governments imposed Islamization or Arabization programs. These citizens believed in the global nature of educational programs and technological training and the sensitive needs to offer equal opportunities to the non-Arab and/or non-Muslim populations to enjoy academic freedoms, especially the right to expose religious texts to liberal interpretations side-by-side with the classical madhahib, and the right to allow local heritages and international literature to thrive creatively in educational curriculums.

\section{International Law and Muslim Teachings}

The OIC announced its commitment "to uphold the objectives and principles of the present Charter, the Charter of the United Nations and international law as well as international humanitarian law while strictly adhering to the principle of non-interference in matters which are essentially within the domestic jurisdiction of any State; to strive to achieve good governance at the international level and the democratization of the international relations based on the principles of equality and mutual respect among States and non-interference in matters which are within their domestic jurisdiction.”

This commitment was extremely required in the light of the existing state of affairs of the world's challenges to establish a new order based on peace, justice, and humanitarian relations between all UN Member States. International law should incorporate Shari'a law to strengthen legal principles and to deepen ethical rules. Serious knowledge, tolerant exchanges, and secular-religious tolerance could be largely applied to ensure possible agreements between these fundamental canons.

Human rights in Islam are most comparable to international human rights norms, except that Islam transcended the worldly rules by high ethical spirituality and super principles of forgiveness to please God in the case of retribution. Subhi 'Abdu Sa'ieed (1994: pp. 330-349) affirmed the human rights in Islam included the rights to life, freedom, equality, justice and fair trial, and the protection from authority's abuses and torture, the protection of blood, property and reputation, and the rights of minorities. Sa'ieed also mentioned the right to refuge, the freedom of movement, and the freedoms of thought, beliefs, and expression; economic rights, the right to protection from treachery, exploitation, dispossession of private property; and the right to work with sufficient returns. Human rights in Islam contained detailed rights to the family well-being and the spouses and children's welfare.

This clear overlapping of the two major sources of human rights for Muslims should have necessitated top attention in application by the law-enforcement agencies. A major problem, however, that curtailed the full enjoyment of these rights was the partisan performance of authorities in the non-Muslim 
countries which denied wrongfully the right of Muslims to disseminate knowledge on Islam peacefully, as stipulated in international norms, and the extremist policies and practices in the Muslim countries which excluded the right of people to exercise freedoms of thought and expression.

Earlier, Kamal Hamid Mugeeth (1995: pp. 89-96) noted that Muslim societies witnessed flourishing civilized thought in the three centuries right after the Prophet's Hijra to Medina. "This is due to the impact of many instruments that regulated the relationships between jurists or thinkers and the fundamental texts of Islam, the Qur'an and the Sunna, and the continuous changes occurring in the social life.”

In Muslim history, according to Mugeeth (1995: p. 89), “the absence of a religious authority to decide on juristic interpretations of the texts, the great consideration Muslim jurists gave to both natural and social phenomena, and the strong presence of the right to exercise freely and creatively the freedom of thought promoted the recognition of the right to disagreement, the prevalence of tolerance, rejection of violence, and the mutual respect of controversial opinions.” What was applied of the Holy Qur'an depended largely on the juristic decision making, besides the personal choice of individuals in Muslim societies. Today, usury, or interest in financial transactions, became a principal activity in the world system. If a Muslim decided to deal with usury, she/he would have to either accept the time's interpretation of usury as a necessary code of contemporary life, or to live in a self-closed subsistence economy as the Christian Mormons did in the US.

\section{Islam and Legal Reforms}

Mahmoud (2013: pp. 338-340) documented with reliable evidence the existence of a strong Islamic judicial system of jurisprudence over long centuries of the Muslim rule of their societies. In modern times, a politico-legislative and executive crisis resulted in a total loss of the independent systematic judiciary the Muslim populations once experienced in old times. A modern substitute, nonetheless, should be established in line with the international principles of justice and independence of the judiciary, in addition to the moral and well-established heritage of the Islamic fiqh which virtually realized standard rules of international norms.

In Muslim nations today, the constitutions of Muslim states must guarantee full independence of the Judiciary as a major branch of government. New legislations must replace authoritative laws, based on contemporary Ijtihad [scholarly studies]. The judges, attorneys, legal academicians, and the other professionals who had been unlawfully dismissed for lawful disputes with state managers should be reinstated in the service of their nations and the needs of judicial reforms. Committees composed of civil judges, academicians, jurists, and democracy and human rights activists must join hand in hand the Shari'a jurists and judges to bring about a new Personal Status Law.

Under a new fair legislation, a woman should have the option via legal consultation to choose a spouse, ask for inheritance, divorce, maintenance, or child custody by Muslim jurisprudence, or to file a case before civil courts by secular civil law. The same procedure was suggested for the non-Muslim populations in Muslim societies. This was what a secular state was all about: the availability of options and alternatives for citizens of the State to decide willingly upon their own affairs without coercive guidance, intrusion, or dictation by State authorities over their choice and preferences, freedoms of expression, belief systems, or personal rights.

\section{Further Observations and Operational Strategies}

What was new in Muslim faith? In this paper, we emphasized the fact that Muslim faith is a constant fact in the life of Muslims all over the world. We discussed a few schools of thought and/or movements that established new Islamic and/or secular formations in the contemporary world system of which the OIC was most prominent. We did find that the OIC exercised pervasive political, ideological, economic, social, and psychological activities as collective articulations in many regional and national locations. We also touched upon national challenges and geopolitical realities interacting in conflict within the OIC and other groups.

This paper indicated genuine differences, as well as possible agreements between authentic tenets of Islam and the international principles on human rights and justice. We felt that the Muslim governmental performance and developmental efforts unfortunately stressed states' security and military build-up, whereas intellectual works addressed the dire need of Muslims to attend key industrial and agricultural advancement, fair production relations, and radical improvements for the life of the vast majority of Muslim populations all over the world. The comparisons highlighted between Muslim entities and the nonMuslim western nations revealed the unattended challenges of progression by Muslim states despite immense pressures for reform by judicial, educational, and other occupational professionals and activists.

The challenges facing Muslim nations today had been equally facing non-Muslim individuals and groups. What was not quite clear for most westerners and other world entities, however, was that the same challenges of living in peace and prosperity with the full enjoyment of human rights and fundamental freedoms for non-Muslim populations resembled the same and one requirement for Muslims to exercise full enjoyment of Islam. As we see it, this philosophical issue is precisely the reason why serious rethinking of East-West, Muslim-nonMuslim hostilities should be strongly advanced to end the crisis.

\section{REFERENCES}

al-Faruqi, Isma’il (2008). Islam and human rights. http//www.ismailfaruqi.com/articles/page/2/

Arab Organization for Human Rights (2001). Annual report on the situation of human rights in the Arab region different reports. Cairo: AOHR.

Baatout, F. (2013). Doha meet raises \$3.6 billion for sudan’s Darfur: Qatar, Relief Web, report from Agence France-Presse .

http://reliefweb.int/report/sudan/qatar-pledges-500-mn-aid-darfur-mi nister-0

Baldauf, S. (2010). Islamic countries pledge \$850 million to develop Darfur. The Christian Science Monitor.

http://www.csmonitor.com/World/Africa/2010/0322/Islamic-countrie s-pledge-850-million-to-develop-Darfur

Barasi, L. (2005). Saudi arabi’a humanitarian aid a political takeover, HPN Humanitarian Practice Network.

http://www.odihpn.org/humanitarian-exchange-magazine/issue-29/sa udi-arabias-humanitarian-aid-a-political-takeover

El Sayed, R. (2003). Al-Tagdid al-fiqhi wal-dini [Renewal of Jurisprudence and Region] (p. 15). Beriut: Dar al-Ijtihad. 


\section{E.-T. MAHMOUD}

El Tigani, M. (2009). Are the Iranian-led Islamists doing justice to the Muslims in Darfur? Paris, Sudan Tribune.

http://www.sudantribune.com/spip.php?article30431

Farooqi, M. I. H. (2012). Status of Muslim societies around the world, Urdu scientific society. Golaganj, Lucknow.

http://www.irfi.org/articles/articles_251_300/status_of_muslim_soci eties_aroun.htm

Fuller, T. (2013). In Myanmar, revival of attacks on Muslims. The New York Times, New York, NY: NYT.

Hendawi, H. (2013). Muslim world divided on Syria, Mali, The Huffington Post.

http://www.huffinftonpost.com/2013/02/06/organization-islamic-coo peration-syria-mali_n_n2630437.html

Ibrahim, A. (2011). The most pressing issues for the Muslim world. Islamic Civil Society of America, Minneapolis. http://icsaweb.org/http:/icsaweb.org/the-most-pressing-issues-for-the -muslim-world/

ICNL (2008). Charter of the organization of Islamic conference. http://www.icnl.org/research/library/files/Transnational/OIC-Charter -En.pdf

International Criminal Court (ICC) (2009). Public document (warrant of arrest), Prosecutor v. Omar Hassan Ahmad al Bashir. http://www.icc-cpi.int/iccdocs/doc/doc639078.pdf IQS International Aid Services (2013). Darfur crisis, Sudan. http://www.ias-intl.org/world_emergency_darfur.php

Mahmoud, M. (2013). The sources of Islamic jurisprudence: Justice and law in Islam. Lewiston: Edewin Mellen Press.

Mugeeth, K. A. (1995). "Min aliyat al-tataruf al-deeni...," [Some mechanisms of religious extremism...] in: Irhab al-Fikr wa Huriyat al-'Ibda' [Intimidating Thought and Freedom of Creative Work]. Cairo: LRRC \& FRCU.

Nabil Loga Babwai (2000). Al-Irhab Sina'a qair Islamiya [Terrorism is a non-Muslim practice. Cairo: al-Ahram Print.

Sa'ieed, S. A. (1994). Al-Islam wa Hugug al-Insan [Islam and Human Rights]. Cairo: Dar al-Nahda al-'Arabiya.

Suparno, R. (2008). New oic charter could spark islamic resistance, Jakarta Post.

http://www.thejakartapost.com/news/2008/03/16/new-oic-charter-co uld-spark

Win, K. M. (2013). Myanmar Muslims hide from Buddhist mobs amid sectarian violence. Huff Post Religion.

http://www.huffingtonpost.com/2013/10/02/myaanmar-muslims_n_4 029018htm 